\title{
Response: Commentary: Is the Neoproterozoic oxygen burst a supercontinent legacy?
}

\author{
Melina Macouin ${ }^{1 *}$, Sonia Rousse ${ }^{1}$, Jérôme Ganne ${ }^{1}$, Yoann Denèle ${ }^{1}$, Damien Roques ${ }^{1}$ and \\ Ricardo I. F. Trindade ${ }^{2}$ \\ 'Géosciences Environnement Toulouse, UMR 5563 Centre National de la Recherche Scientifique, UR234 IRD, Université de \\ Toulouse, Toulouse, France, ${ }^{2}$ Departamento de Geofísica, Instituto de Astronomia, Geofísica e Ciências Atmosféricas, \\ Universidade de São Paulo, São Paulo, Brazil
}

Keywords: rock magnetism, Neoproterozoic Oxygenation Event, hematite-magnetite buffer, Rodinia, Socotra, subductions

\section{A commentary on \\ Commentary: Is the Neoproterozoic oxygen burst a supercontinent legacy? by Nédélec, A., and Borisova, A.Y. (2015). Front. Earth Sci. 3:80. doi: 10.3389/feart.2015.00080}

\section{OPEN ACCESS}

Edited by:

Eric Font,

University of Lisbon, Portugal

Reviewed by:

Dario Bilardello,

University of Minnesota, USA

Nicholas L. Swanson-Hysell,

University of California, Berkeley, USA

Juan Cruz Larrasoaña,

Instituto Geológico y Minero de España, Spain

*Correspondence:

Melina Macouin

melina.macouin@get.omp.eu

Specialty section:

This article was submitted to

Geomagnetism and Paleomagnetism,

a section of the journa

Frontiers in Earth Science

Received: 25 April 2016 Accepted: 19 August 2016 Published: 31 August 2016

Citation:

Macouin M, Rousse S, Ganne J, Denèle $Y$, Roques $D$ and Trindade RIF

(2016) Response: Commentary: Is the Neoproterozoic oxygen burst a supercontinent legacy? Front. Earth Sci. 4:83

doi: 10.3389/feart.2016.00083
We thank Nedelec and Borisova (2015) for giving us the opportunity to clarify our data and (derived) conceptual model. The purpose of Macouin et al. (2015) was to propose a new approach to explain the Neoproterozoic Oxygenation Event. It should be recalled that among the recent and abandoned hypotheses for the oxidation of the atmosphere, rise of less reduced gases (or more oxidized) remains one of the most frequently invoked (i.e., Kasting, 2013).

We illustrate our model with data acquired on the Neoproterozoic Socotra biotite granite (SBG) thought to be related to one of the subduction zones that surrounded Rodinia around $780 \mathrm{Ma}$. The main question raised by Nedelec and Borisova (2015) concerns the primary origin of hematite and ilmenite in this granite and the oxidized character of the emitted gases.

Before discussing the oxide assemblage, we answer on the use of the hematite-magnetite buffer, for which we refer to Sun et al. (2015) and Botcharnikov et al. (2008). Indeed, the magnetitehematite assemblage does not permit to give a precise value of $\triangle \mathrm{FMQ}$, but as stated by these authors, the assemblage is a classical indicator of high oxygen fugacities and hence of an oxidized magma. As mentioned in the comment, it is true that, recently, $\mathrm{fO}_{2}$ from gas has been shown to possibly diverge from the source magma contrary to what was commonly thought previously (i.e., Burgisser and Scaillet, 2007). Nevertheless, these authors have estimated the deviation from the redox state of the magma source by no more than $1.5 \log$ unit at maximum. In our case, we can still invoke oxidized gases since our estimated $\mathrm{fO}_{2}$ from sources is significantly higher $(\Delta \mathrm{FMQ}+4 / 5)$.

Concerning the oxide assemblage found in the SBG, we first state that magmatic or late magmatic origin of (titano-poor) hematite has already been reported. For example, Carvalho and Janasi (2012) found hematite in the 610 Ma Pedra Branca syenite (from a magmatic arc) in Brazil. These authors described a primary assemblage of hematite, ilmenite and magnetite. They conclude that this coexistence implies oxidized conditions and probably high oxygen fugacities. One of the authors herself reports an example of magmatic hematite in the unaltered Washita granite (Nedelec et al., 2015). In this publication, the hematite, in the unaltered granite, is interpreted as due to a change in oxygen fugacity in the magma "without any influence of a hydrous fluid." Also, contrary to what Nedelec and Borisova (2015) advance in their comment, Broska and Petrik (2011) do not state that hematite is always post magmatic but that the reactions could begin in the magmatic stage. 

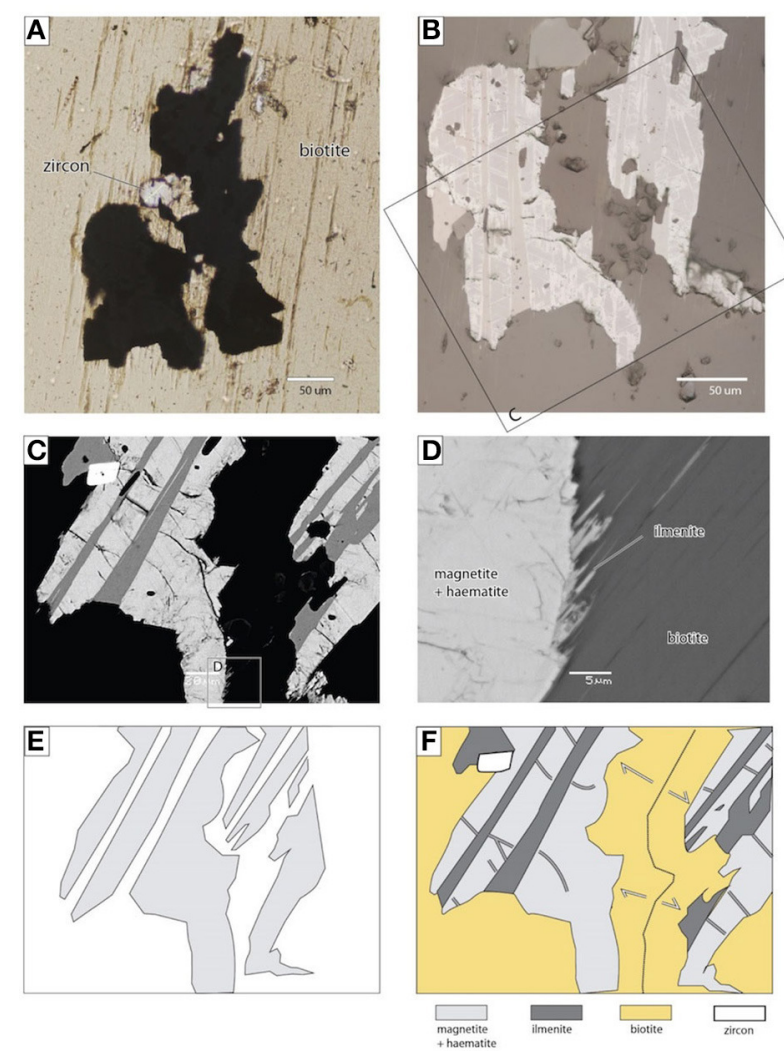

FIGURE 1 | Corrected caption of Figure 7 of Macouin et al. (2015). Photomicrographs of magnetite from CS46 sample (Socotra Biotite Granite, Neoproterozoic terrains, Oman) (A) Photomicrographs of subhedral crystals of magnetite (black minerals) trapped in a poikiloblast crystal of biotite (brown mineral). (B) Recognition of treillis-like shaped hematite within the crystal of magnetite under reflected light microscopy. Note that hematite is present in the ilmenite and at the fringe of the ilmenite lamellae (C) Back-scattered electron imaging on the internal structure of oxide, using a scanning electron microscope (SEM), reveals multiple grains of magnetite-hematite separated by elongated crystals of ilmenite. (D) Oriented needles or patches of ilmenite outline the contact with biotite. (E,F) Interpreted magmatic events depicted from microscopic and SEM observations. Ilmenite and hematite lamellae developed along cleavage planes of magnetite, due to magmatic oxy-exsolution processes. Magnetite was fractured and divided.

Nedelec and Borisova (2015) affirm that liquidus phase hematite was uniquely found in an experimental peralkaline residual (Edgar, 1974), and therefore not possible with natural samples. More recent literature reports formation of liquidus phase hematite on both, for example, I-type Chinese granite, remelted and recrystallized (Liaw et al., 2006) and a synthetic analog of a ferrobasaltic melt of the Skaergaard intrusion (Botcharnikov et al., 2008). These authors even demonstrate that they produce hematite in their experiments only at high oxygen fugacities $\left(\mathrm{fO}_{2}>2.5\right)$. Both these experiments involve formation of titano-poor hematite (and not of stoichiometric hematite) as it is interpreted in the SBG. This interpretation is strongly suggested by the reversible behavior of the thermomagnetic curves with Néel temperatures on the order of $620^{\circ}-630^{\circ} \mathrm{C}$ (see samples CS27-CS30 from
Figure 4, Macouin et al., 2015) combined with the petrological observations.

We are aware that hematite can be secondary in granites due to oxygenated fluids. Such secondary hematite has been described in different forms described in Nedelec et al. (2015), or associated with chloritized biotite (Just and Kontny, 2012). A typical mark of hematitization (maghemitization) of titano-magnetite is to display a progression from rims toward core center (often with the core untouched) or along the fractures (Figure $4 \mathrm{H}$ of Broska and Petrik, 2011). Curved cracks are also a typical feature of maghemitization (Figure 15 of Haggerty, 1991; Figure 3C of McEnroe and Brown, 2000). It is worth noting that in the SBG, the hematite does not appear into any of these forms and marks of alteration are absent (Figure 1).

In the SBG, as described by Haggerty (1991), the C4 stage is probably reached in the samples presenting the assemblage of magnetite-ilmenite-hematite. It is difficult to assess whether the hematite lamellae replaced previous thin ilmenite lamellae (as expected for C4 stage) or are secondary as Nedelec and Borisova (2015) argue. Nevertheless, in Figure 1B, thick ilmenite lamellae are seen to both contain hematite and be fringed by hematite, indicating the C4 stage. While we think that this stage was attained during the formation of the granite, late magmatic deuteric oxidation (above $600^{\circ} \mathrm{C}$ ) could not completely be excluded. In this case, such a high temperature alteration would indicate high fugacity of oxygen at least in the fluids that were involved during the end or just after the crystallization as likely occured in the Malani red rhyolites described by Torsvik et al. (2001).

Furthermore, contrary to what Nedelec and Borisova (2015) claim, porphyries generally present hematite-magnetite assemblages and their primary origin has recently been evoked by Sun et al. (2013, 2015). As stated by Sun et al. (2013), intergrowths of magnetite-hematite, such as the ones we exposed in our paper (Macouin et al., 2015), are not often studied and may represent a challenge. It appears clearly that their occurrences are rare and therefore represent an unusual feature. The fact that hematite is ignored or systematically referred as secondary might be a bias in the studies.

Finally, the hematite in the SBG seems to be likely primary and our model remains a possible valid explanation for the NOE. This interesting discussion emphasizes the need to scrutinize this type of mineralogical assemblage in further studies. Additional methods could be used for that, such as paleomagnetic direction to decipher the synchronicity in hematite and magnetite formation or in-situ geochemistry.

\section{AUTHOR CONTRIBUTIONS}

All authors listed, have made substantial, direct and intellectual contribution to the work, and approved it for publication.

\section{FUNDING}

The study was supported by the Tellus-Syster, PNP and Marges programs of the INSU-CNRS and by the OMP-AO1 program. 


\section{REFERENCES}

Botcharnikov, R. E., Almeev, R. R., Koepke, J., and Holtz, F. (2008). Phase relations and liquid lines of descent in hydrous ferrobasalt - Implications for the Skaergaard intrusion and Columbia River flood basalts. J. Petrol. 49, 1687-1727. doi: 10.1093/petrology/egn043

Broska, I., and Petrik, I. (2011). Accessory Fe-Ti oxides in the West-Carpathian I-type granitoids: witnesses of the granite mixing and late oxidation processes. Mineral. Petrol. 102, 87-97. doi: 10.1007/s00710-011-0158-6

Burgisser, A., and Scaillet, B. (2007). Redox evolution of a degassing magma rising to the surface. Nature 445, 194-197. doi: 10.1038/nature05509

Carvalho, B. B., and Janasi, V. D. A. (2012). Crystallization conditions and controls on trace element residence in the main minerals from the Pedra Branca Syenite, Brazil: an electron microprobe and LA-ICPMS study. Lithos 153, 208-223. doi: 10.1016/j.lithos.2012.05.003

Edgar,A.D. (1974). "Experimental studies," in The Alkaline Rocks, ed H. Sorensen (London: John Wiley and sons), 355-389.

Haggerty, S. E. (1991). “Oxide textures: a mini atlas," in Oxide Minerals: Petrologic and Magnetic Significance, Vol. 25, ed D. H. Lindsley (Washington, DC: Mineralogical Society of America), 129-219.

Just, J., and Kontny, A. (2012). Thermally induced alterations of minerals during measurements of the temperature dependence of magnetic susceptibility: a case study from the hydrothermally altered Soultz-sous-Forets granite, France. Int. J. Earth Sci. 101, 819-839. doi: 10.1007/s00531-011-0668-9

Kasting, J. F. (2013). What caused the rise of atmospheric O-2? Chem. Geol. 362, 13-25. doi: 10.1016/j.chemgeo.2013.05.039

Liaw, C. W., Liu, T. C., Iizuka, Y., and Yang, H. Y. (2006). Anhydrous melting and crystallization of granite from the transition zone of the Qilian orogenic belt, NW China: an experimental study at atmospheric pressure. Terrestrial Atmos. Oceanic Sci. 17, 233-251.

Macouin, M., Roques, D., Rousse, S., Ganne, J., Denèle, Y., and Trindade, R.I. F. (2015). Is the Neoproterozoic oxygen burst a supercontinent legacy? Front. Earth Sci. 3:44. doi: 10.3389/feart.2015.00044
McEnroe, S. A., and Brown, L. L. (2000). Palaeomagnetism, rock magnetism and geochemistry of Jurassic dykes and correlative redbeds, Massachusetts, USA. Geophys. J. Int. 143, 22-38. doi: 10.1046/j.1365-246x.2000.00193.x

Nedelec, A., and Borisova, A. Y. (2015). Commentary "Is the Neoproterozoic oxygen burst a supercontinent legacy?" Front. Earth Sci. 3:80. doi: 10.3389/feart.2015.00080

Nedelec, A., Trindade, R., Peschler, A., Archanjo, C., Macouin, M., Poitrasson, F., et al. (2015). Hydrothermally-induced changes in mineralogy and magnetic properties of oxidized A-type granites. Lithos 212, 145-157. doi: 10.1016/j.lithos.2014.11.007

Sun, W. D., Liang, H. Y., Ling, M. X., Zhan, M. Z., Ding, X., Zhang, H., et al. (2013). The link between reduced porphyry copper deposits and oxidized magmas. Geochim. Cosmochim. Acta 103, 263-275. doi: 10.1016/j.gca.2012. 10.054

Sun, W., Huang, R.-F., Li, H., Hu, Y.-B., Zhang, C.-C., Sun, S.-J., et al. (2015). Porphyry deposits and oxidized magmas. Ore Geol. Rev. 65, 97-131. doi: 10.1016/j.oregeorev.2014.09.004

Torsvik, T. H., Carter, L. M., Ashwal, L. D., Bhushan, S. K., Pandit, M. K., and Jamtveit, B. (2001). Rodinia refined or obscured: palaeomagnetism of the Malani igneous suite (NW India). Precambrian Res. 108, 319-333. doi: 10.1016/S0301-9268(01)00139-5

Conflict of Interest Statement: The authors declare that the research was conducted in the absence of any commercial or financial relationships that could be construed as a potential conflict of interest.

Copyright (๔ 2016 Macouin, Rousse, Ganne, Denèle, Roques and Trindade. This is an open-access article distributed under the terms of the Creative Commons Attribution License (CC BY). The use, distribution or reproduction in other forums is permitted, provided the original author(s) or licensor are credited and that the original publication in this journal is cited, in accordance with accepted academic practice. No use, distribution or reproduction is permitted which does not comply with these terms. 